Aleksandra Mależyna

olamalezyna@interia.pl

\title{
Eventy sportowe jako czynnik rozwoju turystyki na obszarach goszczących (na przykładzie siatkarskich imprez organizowanych w Krakowie)
}

\section{Streszczenie}

Kraków dzięki doskonałemu położeniu komunikacyjnemu, infrastrukturze sportowej - TAURON Arena Kraków - może być areną wielkich wydarzeń sportowych. Rozdział poza zagadnieniami teoretyczno-terminologicznymi zawiera analizę wpływu Memoriału Huberta Jerzego Wagnera i Mistrzostw Europy Siatkarzy 2017 na gospodarkę Krakowa w świetle własnych badań empirycznych. Celem badań była próba wykazania, w jakim stopniu kibice podejmują dodatkową aktywność turystyczną w mieście przy okazji udziału w tych eventach. Imprezy siatkarskie typu mistrzowskiego generują większy ruch turystyczny, przyciągają większą liczbę osób spoza obszaru, w którym się odbywają. Osoby te łączą kibicowanie ze zwiedzaniem miejsca, w którym przebywają, dłużej zostają w Krakowie i chcą skorzystać m.in. z bogatej oferty kulturalnej.

\section{Wprowadzenie}

Obserwowany w ostatnich latach wzrost liczby eventów sportowych przyczynia się do zwiększonego zainteresowania ze strony kibiców, dla których uczestnictwo w tego typu wydarzeniach stało się popularną formą spędzania czasu wolnego. Podróże kibiców zainteresowanych sportem, zaangażowanie w tworzenie ważnych eventów oraz zainteresowanie sławnymi sportowcami powoduje, że fani stają się także turystami przebywającymi na miejscu istotnych wydarzeń. Organizacja imprez sportowych przynosi nie tylko wymierne korzyści materialne, ale także przyczynia się do promocji danego miejsca bądź regionu. Kraków

Cytowanie: Mależyna A. (2021). Eventy sportowe jako czynnik rozwoju turystyki na obszarach goszczących (na przykładzie siatkarskich imprez organizowanych w Krakowie). W: K. Borodako (red.), Turystyka w okresie pandemii. Bogucki Wydawnictwo Naukowe, Poznań-Kraków, s. 36-47. https://doi.org/10.12657/9788379863501-4 
W widoczny sposób zaznacza swoją pozycję na mapie wydarzeń organizowanych w Polsce i na świecie. Dotyczy to zwłaszcza okresu po roku 2014, kiedy oddano do użytku główny obiekt - TAURON Arena Kraków. Przyczyniło się to do organizacji w mieście różnych eventów sportowych na skalę krajową i międzynarodową. Kibicowanie ulubionym zespołom sprzyja wspólnemu przeżywaniu emocji oraz integracji społecznej. Siatkarskie eventy cieszą się ogromną popularnością. Jak podał Polski Związek Piłki Siatkowej, Mistrzostwa Europy Siatkarzy 2017 (LOTTO EUROVOLLEY POLAND 2017) obejrzało na żywo 213089 kibiców (z czego ponad $40 \%$ zasiadło na trybunach PGE Stadionu Narodowego, ERGO Arena Gdańsk/Sopot i TAURON Arena Kraków) oraz miliony telewidzów z całej Europy dzięki przekazom medialnym. Według raportu „Wpływ i działanie promocyjne polskich miast i regionów. Edycja 2018" Kraków, w porównaniu do miast takich, jak: Warszawa, Toruń czy Katowice, przeznaczył zaledwie $10 \mathrm{mln}$ zł na wydatki promocyjne. Włodarze miasta zdają sobie sprawę, że organizacja eventów niesie ze sobą także dodatkową wartość medialną. Kraków dzięki doskonałemu położeniu, sprawnie działającej komunikacji, bardzo dobrej bazie noclegowej, nowo powstałej infrastrukturze sportowej może być areną wielkich wydarzeń siatkarskich zarówno niższej rangi, jak i mistrzowskiej. Celem badań, przeprowadzonych w 2017 r. na potrzeby pracy magisterskiej, była próba wykazania, w jakim stopniu kibice podejmują dodatkową aktywność turystyczną w mieście przy okazji udziału w eventach, oraz dowiedzenia, że siatkarskie imprezy sportowe są czynnikiem, mającym wpływ na rozwój turystyki w mieście. Analizy miały na celu pozyskanie informacji, która $z$ dwóch prestiżowych imprez: towarzyska - Memoriał Huberta Jerzego Wagnera, rozgrywany w stolicy województwa małopolskiego cyklicznie od roku 2016 - bądź mistrzowska - Mistrzostwa Europy Siatkarzy 2017 - ma większy wpływ na gospodarkę Krakowa. Należy podkreślić, że badaniami objęto niewielką grupę kibiców biorących udział w Memoriale Jerzego Huberta Wagnera oraz Mistrzostwach Europy Siatkarzy w 2017 r. w Krakowie. Liczba otrzymanych ankiet nie pozwala na uogólnienia, umożliwia natomiast formułowanie pewnych wniosków dotyczących przebadanej próby.

\section{Przegląd literatury}

Termin „event” wywodzi się z języka angielskiego i w dosłownym tłumaczeniu na język polski oznacza „wydarzenie”. Określenie to jest jednak zbyt ogólne i mylące, gdyż nie każde wydarzenie można nazwać eventem. Trudno w języku polskim znaleźć precyzyjny termin, który oddawałby znaczenie owego słowa. W literaturze przedmiotu odszukano kilka definicji.

Event - to niecodzienne i wyjątkowe, aczkolwiek zaplanowane, wydarzenie dla ludzi, które ma za pomocą określonego budżetu i nakładów pracy ludzkiej dostarczyć przeżyć i emocji, będących celem organizatora, przy czym cel ten może mieć znaczenie $\mathrm{w}$ aspekcie marketingowym, PR-owym, politycznym, społecznym, rekreacyjnym, kulturalnym, dobroczynnym lub psychologicznym (Bączek, 2011, s. 13). 
Same wydarzenia marketingowe, nazywane również imprezami specjalnymi, definiowane są jako jednorazowe lub rzadko powtarzane wydarzenia poza normalnym programem działania sponsorów lub organizatorów, będące dla konsumenta okazją do przeżycia o charakterze rekreacyjnym, społecznym lub kulturalnym, wykraczające poza powszechnie dostępne oferty lub codzienne doświadczenia (Richards, 2004, s. 17)

„Ich znaczenie jako narzędzia komunikacji marketingowej, której celem jest m.in. budowanie wizerunku, wynika z ich interaktywności oraz zdolności do wzbudzania zainteresowania mediów" (Proszowska-Sala, Florek, 2010, s. 204). Niemieccy badacze Gebhard i Hitzer (2000) dość szczegółowo definiują owe zjawisko. Według nich eventy to wydarzenia niecodzienne, masowe spektakle łączące różnorodne elementy. $\mathrm{Z}$ reguły zorganizowane $\mathrm{w}$ celach komercyjnych, których nadrzędnym zadaniem jest dostarczenie silnych emocji. Przykładowo Bączek (2011) dzieli eventy na kilka rodzajów, m.in. ze względu na dostępność (zamknięte - wstęp biletowany, otwarte - powszechne), czas trwania (jedno-, wielodniowe, etapowe), formę (filmowe, sportowe, muzyczne, multimedialne, rekreacyjne). W anglojęzycznych źródłach znaleziono podział według Getz (2005) ze względu na rodzaj m.in. na: wydarzenia polityczne i państwowe (wizyty VIP-ów, szczyty), biznesowe i handlowe (targi, wystawy, spotkania itd.), rozgrywki sportowe (profesjonalne, amatorskie) oraz zasięg oddziaływania: megaeventy (transmitowane na całym świecie, przygotowywane z wyprzedzeniem, np. Mistrzostwa Europy w Piłce Siatkowej), hallmark event (kojarzone z danym miastem bądź państwem, unikatowy produkt turystyczny, np. Memoriał Huberta Jerzego Wagnera), regionalne eventy (mniejszej rangi, wypromowane na arenie krajowej, typu mistrzostwa krajowe w danej dyscyplinie), lokalne eventy (nieduże imprezy o niskim budżecie i frekwencji widzów - rozgrywki lokalnych drużyn). W polskiej i obcojęzycznej literaturze przedmiotu nie ma jednoznacznie sformułowanej i powszechnie obowiązującej typologii eventów. Jest to na tyle młode i dynamicznie rozwijające się zjawisko, że można je klasyfikować według różnych kryteriów.

\section{Eventy sportowe}

Specyficznymi wydarzeniami z uwagi na znaczący wpływ na rozwój turystyki są eventy sportowe. „Udział w wydarzeniu sportowym często stymuluje poczucie jedności wśród jego uczestników, wspólne przeżywanie emocji i doznań z innymi osobami dzielącymi podobne zainteresowania, niepowtarzalność przeżyć, rywalizację zawodników i znaczący wydźwięk w przekazie medialnym” (Poczta, Malchrowicz-Mośko, 2016, s. 154). Wyżej wspomniane autorki zwracają także uwagę na aktywność turystyczną biernych uczestników eventów sportowych przy okazji badań przeprowadzonych w Poznaniu. Literatura przedmiotu mianem eventu o charakterze sportowym określa wydarzenie, które podlega pewnym zasadom i rytuałom panującym w konkretnej dyscyplinie sportu. Jak zauważa Freyer (1998), kibice interesują się tego typu imprezami ze względu na: 
- widowiskowość i efektywność,

- ogarniające podekscytowanie i niepewność co do ostatecznego rezultatu sportowego pojedynku,

- oczekiwane show oraz rozrywkę,

- duże zainteresowanie medialne możliwe dzięki środkom masowego przekazu,

- zainteresowanie ze strony sponsorów,

- utożsamianie się „fanów” ze swoimi ulubionymi drużynami sportowymi bądź sławnymi sportowcami.

\section{Metodyka badań}

Na potrzeby pracy magisterskiej przeprowadzono badania, w których wzięli udział kibice sportowi uczestniczący w imprezie o charakterze towarzyskim Memoriale Huberta Jerzego Wagnera oraz mistrzowskim - Mistrzostwach Europy Siatkarzy 2017 (LOTTO EUROVOLLEY POLAND 2017). Populację badawczą stanowili kobiety i mężczyźni. Wykorzystano do tego metodę kwestionariusza ankietowego. Opracowano dwa podobne kwestionariusze ankietowe, które składały się z 19 pytań głównych oraz 6 pytań metryczkowych, dotyczących ogólnych cech społeczno-demograficznych respondentów. Wśród pytań głównych dominowały półotwarte jednokrotnego wyboru (obok pytania można było wpisać dodatkową odpowiedź, uznaną za istotną $\mathrm{w}$ danej kwestii) oraz dwa pytania otwarte odnoszące się do najważniejszych atrakcji turystycznych Krakowa i procentowego udziału środków pieniężnych na poszczególne kategorie wydatków. Pojawiły się pytania ogólne, na które odpowiedzi były udzielane przez wszystkich respondentów, oraz pytania szczegółowe dedykowane wyłącznie kibicom, którzy na stałe nie mieszkają w Krakowie i poza zamiarem kibicowania przybyli także w celach turystycznych. Ankiety skierowano do osób posługujących się językiem polskim. Dane do analizy zebrano na terenie obiektu TAURON Arena Kraków 11 sierpnia 2017 r. w trakcie Memoriału Huberta Jerzego Wagnera przed meczami: RosjaKanada oraz Polska-Francja, a także 26 sierpnia 2017 r. w trakcie Mistrzostw Europy Siatkarzy 2017 przed meczami fazy grupowej: Słowenia-Rosja oraz Bulgaria-Hiszpania. Łącznie uzyskano 168 poprawnie wypełnionych kwestionariuszy ankiety (odpowiednio po 84 kwestionariusze w trakcie każdego wydarzenia sportowego). Zebrane informacje umożliwiły oszacowanie, jaki procent badanych nocuje w Krakowie, a jaki w pobliskich miejscowościach, $z$ jakiego rodzaju obiektów korzystano, ile dni spędzono w Krakowie oraz jaki procent środków pieniężnych przeznaczono na poszczególne kategorie wydatków. Pytanie dotyczące najważniejszych atrakcji turystycznych, które respondenci planowali zobaczyć w trakcie pobytu w Krakowie, pozwoliło stworzyć ranking obiektów, które cieszą się największą popularnością. Analizę statystyczną wyników badania ankietowego wykonano za pomocą specjalnie przygotowanego w arkuszu kalkulacyjnym Excel narzędzia do gromadzenia, porządkowania, klasyfikowania oraz podsumowywania wyników. Pozwoliło to na opracowanie zebranego materiału statystycznego i prezentację danych $\mathrm{w}$ formie tabeli, w której symbolem $N$ oznaczono 
liczbę odpowiedzi, oraz kołowych i słupkowych wykresów statystycznych. Liczba otrzymanych ankiet nie pozwala na uogólnienia, umożliwia za to formułowanie pewnych wniosków odnośnie do przebadanej próby.

\section{Wyniki badań}

Badania poruszają kilka ważnych kwestii z punktu widzenia włodarzy miast. Czy warto organizować jednorazowe mega eventy na wielką skalę czy lepiej cykliczne hallmark event takie jak Memoriał Huberta Jerzego Wagnera. Należy podkreślić, że badaniami objęto niewielką grupę kibiców biorących udział w obu wydarzeniach sportowych w Krakowie.

Po zakończeniu meczów znaczna większość respondentów w ramach Memoriału Huberta Jerzego Wagnera (73,8\%) i Mistrzostw Europy Siatkarzy 2017 $(88,1 \%)$ nocowała w Krakowie. Należy dodać, że w grupie tej znalazły się także osoby, które na stałe mieszkają w Krakowie - w przypadku Memoriału Jerzego Huberta było to 26 ankietowanych, a Mistrzostw Europy - 20.

Podczas Memoriału Huberta Jerzego Wagnera 22 z 84 badanych respondentów $(26,2 \%)$ nocowało poza Krakowem. Wszystkie te osoby przebywały w miejscowościach na terenie województwa małopolskiego. Prawdopodobnie ma na to wpływ odpowiednia infrastruktura drogowa oraz stosunkowo niewielka odległość dzieląca te miejscowości od Krakowa (maksymalnie 70 km).

Dla porównania w przypadku Mistrzostw Europy Siatkarzy 2017 zaledwie 10 z 84 przebadanych respondentów (czyli 11,9\%) nocowało poza Krakowem. 4 osoby w Bielsku-Białej w województwie śląskim oraz w województwie małopolskim po 2 osoby w Łękawicy (powiat wadowicki), Mszanie Dolnej (powiat limanowski) i Zakopanem (powiat tatrzański). Dla wszystkich ankietowanych były to miejscowości ich stałego pobytu.

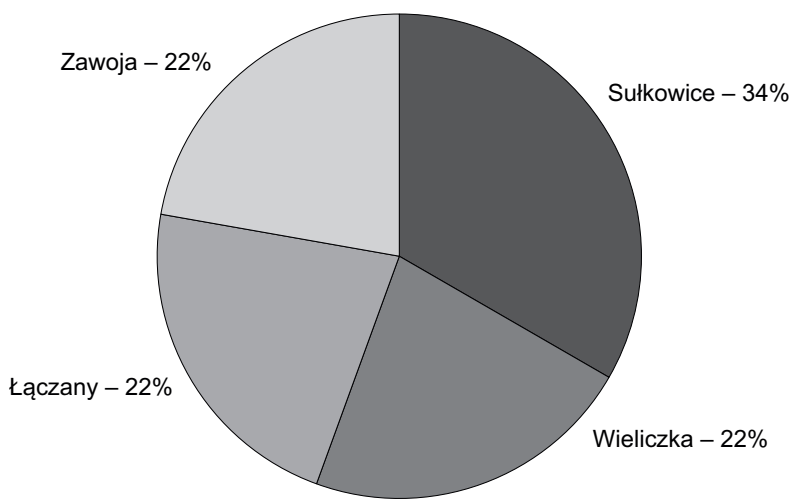

Ryc. 1. Miejsce pobytu respondentów po meczach Memoriału Huberta Jerzego Wagnera poza Krakowem

Źródło: opracowanie własne. 


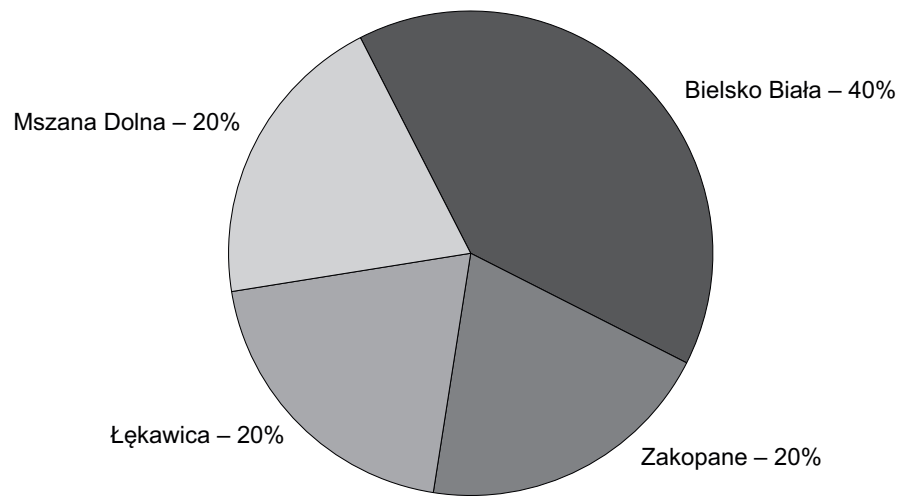

Ryc. 2. Miejsce pobytu respondentów po meczach Mistrzostw Europy Siatkarzy 2017 poza Krakowem

Źródło: opracowanie własne.

Zróżnicowanie bazy noclegowej jest ważnym czynnikiem wpływającym na atrakcyjność danego miasta. Wyniki badań jednoznacznie pokazują, że preferencje respondentów Memoriału Huberta Jerzego Wagnera oraz Mistrzostw Europy Siatkarzy 2017 są odmienne. Z krakowskiej bazy noclegowej nie korzystało łącznie 88,1\% uczestników Memoriału Huberta Jerzego Wagnera oraz 47,6\% uczestników Mistrzostw Europy Siatkarzy 2017. Podczas eventu niższej rangi 31\% osób nocowało u krewnych lub przyjaciól, dla porównania zaledwie 11,9\% w trakcie Mistrzostw Europy Siatkarzy 2017. Kategorię „,inne” w przypadku Memoriału Huberta Jerzego Wagnera stanowiły osoby, które na co dzień mieszkają w Krakowie $(30,9 \%)$ oraz $26,2 \%$ mieszkających na stałe w sąsiednich miejscowościach, takich jak: Sułkowice (7\%), Wieliczka (6,4\%), Zawoja (6,4\%) i Łączany $(6,4 \%)$. Wśród uczestników Memoriału korzystających z krakowskiej bazy noclegowej największą popularnością cieszyły się hotele (szczególnie 3-gwiazdkowe)/motele, wybrało je 7,1\% respondentów. Zauważono, że osoby uczestniczące w meczach Mistrzostw Europy Siatkarzy 2017 częściej korzystały z krakowskich obiektów noclegowych $(52,4 \%)$. Największą popularnością cieszyły się hostele $(28,6 \%)$, a średnio co czwarty fan piłki siatkowej zatrzymał się w hotelu/motelu. Najczęściej wybierano hotele 3-gwiazdkowe bądź 4-gwiazdkowe. Kategorię „inne” stanowiło: 23,8\%

Tabela 1. Rodzaj obiektu noclegowego wybrany przez respondentów

\begin{tabular}{lcccc}
\hline \multirow{2}{*}{ Rodzaj obiektu } & \multicolumn{2}{c}{$\begin{array}{c}\text { Memoriał Huberta } \\
\text { Jerzego Wagnera }\end{array}$} & \multicolumn{2}{c}{ Mistrzostwa Europy } \\
& Siatkarzy & 2017 \\
\cline { 2 - 5 } & $\mathrm{N}$ & $\%$ & $\mathrm{~N}$ & $\%$ \\
\hline Hotel/motel & 6 & 7,1 & 20 & 23,8 \\
Hostel & 4 & 4,8 & 24 & 28,6 \\
Pensjonat & 0 & 0 & 0 & 0 \\
Mieszkanie u krewnych/znajomych & 26 & 31,0 & 10 & 11,9 \\
Inna & 48 & 57,1 & 30 & 35,7 \\
Razem & 84 & 100,0 & 84 & 100,0 \\
\hline
\end{tabular}

Źródło: opracowanie własne. 
osób z Krakowa oraz 11,9\% mieszkających na stałe w Bielsku-Białej (4,7\%), Łękawicy (2,4\%), Mszanie Dolnej (2,4\%) i Zakopanem (2,4\%). Pensjonaty nie były obiektami wybieranymi przez respondentów obu imprez sportowych.

Analiza rozkładu uzyskanych odpowiedzi pozwala wysunąć wnioski, że osoby uczestniczące w towarzyskiej imprezie sportowej decydowały się spędzić w Krakowie 1 dzień bez noclegu (37,9\%) bądź 2 dni (46,6\%). Wynik ten jest następstwem faktu, że pobytom jednodniowym służy niewielka odległość pomiędzy miejscowością zamieszkaną a odwiedzaną. Na pobyt 3-4-dniowy i dłuższy decydowały się osoby spoza województwa małopolskiego. Ankietowani uczestniczący w meczach Mistrzostw Europy Siatkarzy 2017 częściej deklarowali chęć dłuższego pobytu. Co drugi z nich planował spędzić w Krakowie 3 dni, natomiast średnio co czwarty 4 dni i więcej.

Tabela 2. Długość pobytu w Krakowie

\begin{tabular}{lcccc}
\hline \multirow{2}{*}{ Długość pobytu } & \multicolumn{2}{c}{$\begin{array}{c}\text { Memoriał Huberta } \\
\text { Jerzego Wagnera }\end{array}$} & \multicolumn{2}{c}{$\begin{array}{c}\text { Mistrzostwa Europy } \\
\text { Siatkarzy } 2017\end{array}$} \\
\cline { 2 - 5 } & $\mathrm{N}$ & $\%$ & $\mathrm{~N}$ & $\%$ \\
\hline 1 dzień (bez noclegu) & 22 & 37,9 & 10 & 15,6 \\
$2 \mathrm{dni}$ & 27 & 46,6 & 7 & 10,9 \\
$3 \mathrm{dni}$ & 6 & 10,3 & 32 & 50,0 \\
4 dni i więcej & 3 & 5,2 & 15 & 23,5 \\
Razem* & 58 & 100,0 & 64 & 100,0 \\
\hline
\end{tabular}

Źródło: opracowanie własne.

* W analizie wyników nie uwzględniono ankietowanych, którzy na co dzień mieszkają w Krakowie 26 osób w przypadku Memoriału Huberta Jerzego Wagnera oraz 20 osób podczas Mistrzostw Europy Siatkarzy 2017.

Poznanie, jaki procent środków pieniężnych respondenci mieszkający poza Krakowem przeznaczą na nocleg, wyżywienie, komunikację, program turystyczny, pamiątki i „inne”, pozwoli określić, na którą kategorię wydatków przeznaczą najwięcej pieniędzy. W poniższej analizie podzielono ankietowanych na tych, którzy przybyli do Krakowa na 1 dzień bez noclegu oraz 2-4 dni i dłużej. Największą kategorią wydatków dla uczestników obu wydarzeń, którzy spędzili w Krakowie 1 dzień bez noclegu, były koszty wyżywienia. W przypadku osób zasiadających na trybunach Memoriału Huberta Jerzego Wagnera drugą kategorię wydatków pod względem wielkości stanowiły tzw. koszty „inne” 25,8\%, w ramach których wymieniano głównie zakupy. Dla porównania osoby uczestniczące w Mistrzostwach Europy Siatkarzy 2017 na drugim miejscu wskazywały koszty związane z programem turystycznym $(24,7 \%)$.

Natomiast w przypadku 2-4-dniowych i dłuższych pobytów w Krakowie procentowy rozkład środków pieniężnych prezentował się nieco inaczej. Podobnie jak przy 1-dniowych pobytach bez noclegu, największą kategorię wydatków dla ankietowanych zarówno na Memoriale Huberta Jerzego Wagnera (33,5\%), jak i Mistrzostwach Europy Siatkarzy 2017 (30,5\%) stanowiły koszty wyżywienia. Na drugim miejscu uplasowały się wydatki związane z programem turystycznym,. 


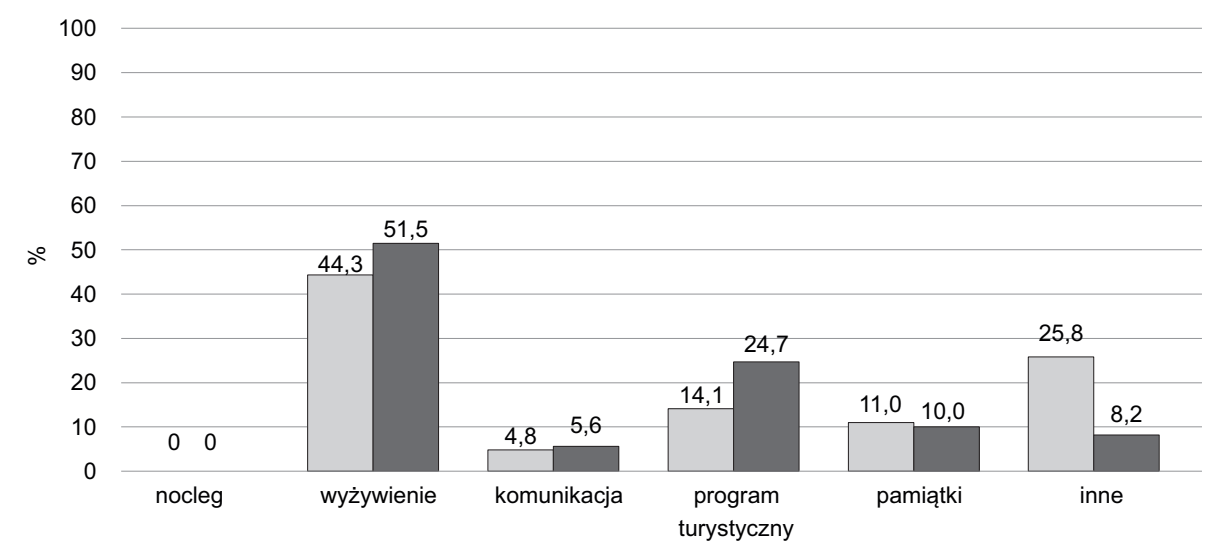

$\square$ Memoriał Huberta Jerzego Wagnera $\quad \square$ Mistrzostwa Europy Siatkarzy 2017

Ryc. 3. Planowane wydatki respondentów w trakcie 1-dniowego pobytu bez noclegu w Krakowie

Źródło: opracowanie własne.

Osoby uczestniczące w Mistrzostwach Europy przeznaczyły więcej pieniędzy na nocleg. Ankietowani deklarujący dłuższy pobyt w Krakowie wydali także więcej na komunikację, która umożliwiła im sprawne poruszanie się po mieście. Najmniejszą część środków pieniężnych przeznaczano na zakup pamiątek.

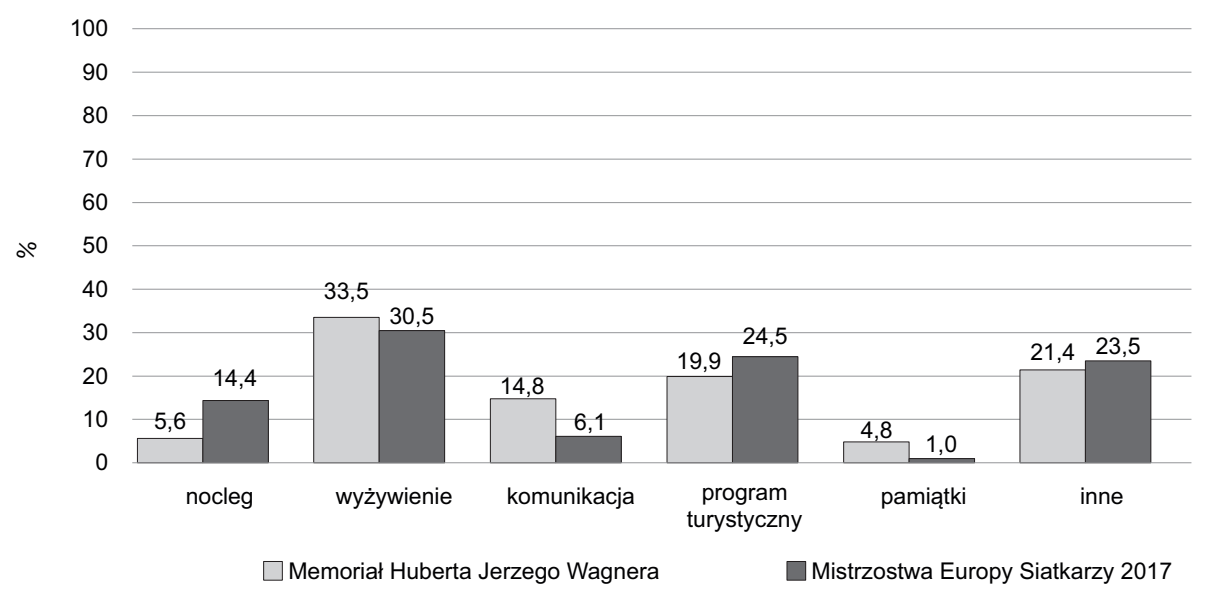

Ryc. 4. Planowane wydatki respondentów w trakcie 2-4-dniowego i dłuższego pobytu w Krakowie

Źródło: opracowanie własne.

Badani respondenci mieszkający poza Krakowem zostali poproszeni o wskazanie 3 głównych atrakcji zlokalizowanych na terenie miasta, które chcieliby zobaczyć w trakcie swojego pobytu. Pytanie to miało charakter otwarty, gdyż w żaden sposób nie chciano nic sugerować respondentom i ograniczać ich wyboru. Odpowiedzi pozwoliły określić stopień popularności danej atrakcji turystycznej 
oraz stan wiedzy ankietowanych na temat krakowskich atrakcji. Za najważniejsze obiekty turystyczne Krakowa uznano Wawel, Sukiennice i Fabrykę Oskara Schindlera. W obu przypadkach $100 \%$ respondentów wymieniło Wawel jako sztandarową atrakcję Krakowa. Świadczy to o stabilnej pozycji tego obiektu jako „perły miasta Krakowa".

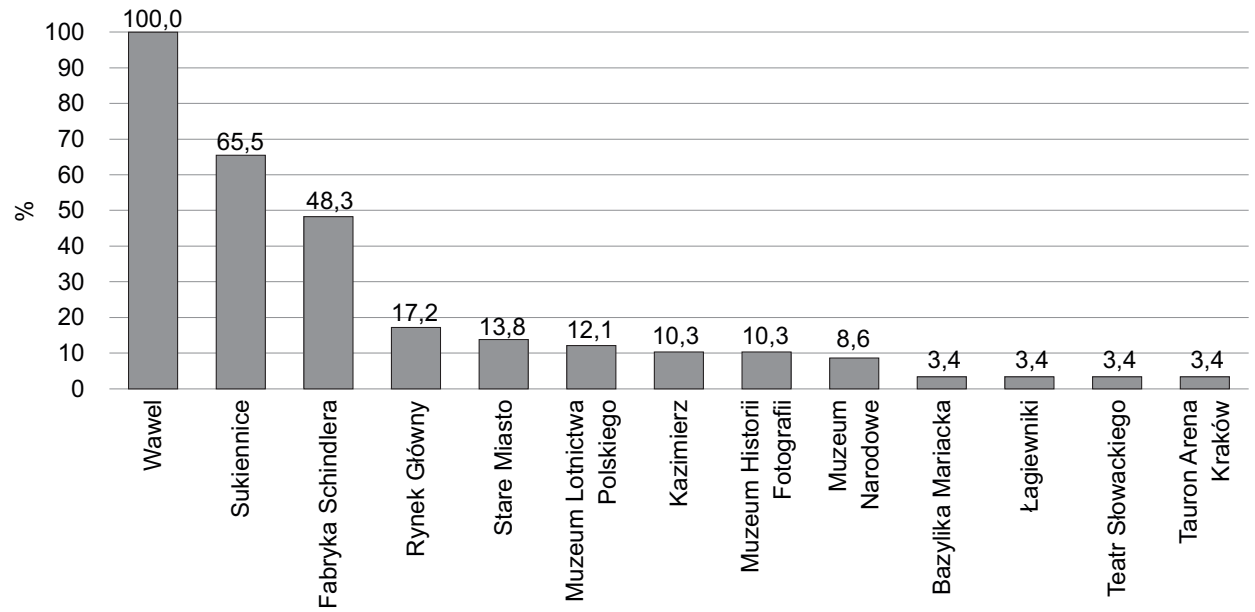

Ryc. 5. Ranking atrakcji Krakowa według respondentów biorących udział w Memoriale Huberta Jerzego Wagnera

Źródło: opracowanie własne.

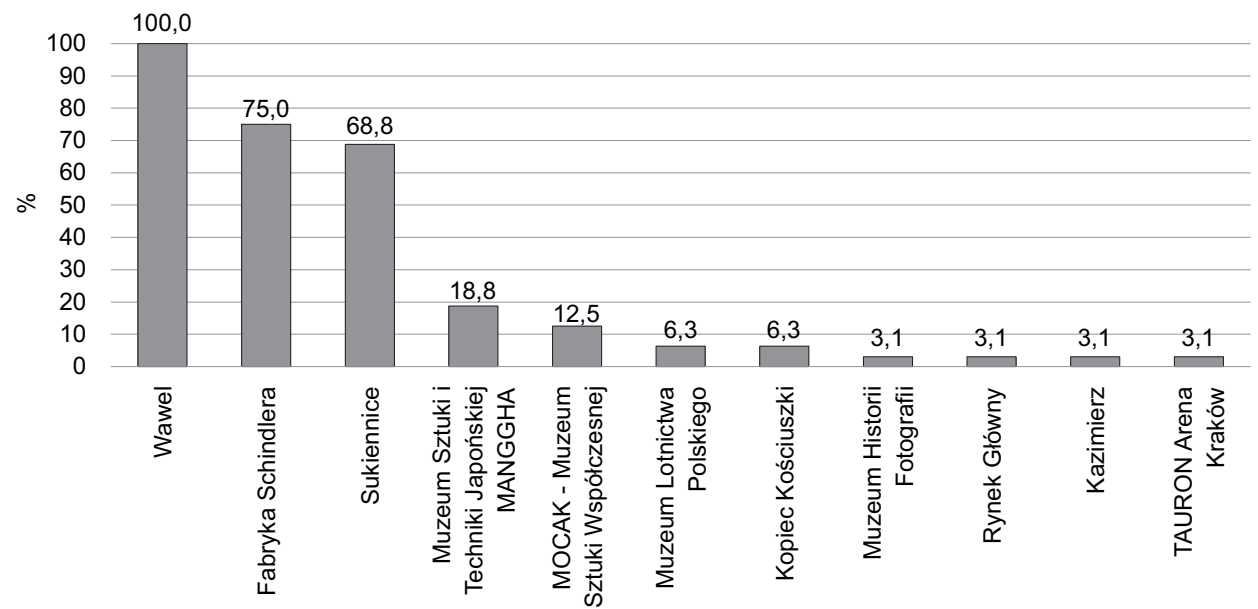

Ryc. 6. Ranking atrakcji Krakowa według respondentów biorących udział w Mistrzostwach Europy Siatkarzy 2017

Źródło: opracowanie własne.

Natomiast trzy czwarte respondentów Mistrzostw Europy Siatkarzy 2017 planowało zobaczyć Fabrykę Schindlera oraz Sukiennice $(68,8 \%)$. Pozostałe atrakcje Krakowa wymieniane przez uczestników obu imprez nie przekraczają $20 \%$. 


\section{Zakończenie}

Imprezy sportowe cieszą się ogromnym zainteresowaniem, gromadząc przy tym rzeszę wiernych kibiców. Niosą korzyści nie tylko jej uczestnikom, władzom lokalnym, ale przede wszystkim są bodźcem zmian gospodarczych oraz istotnym czynnikiem wpływającym na rozwój turystyki. Współcześnie sport jest formą promocji miasta i kreowania pozytywnego wizerunku jakieś destynacji. Władze miast konkurują między sobą o organizowanie prestiżowych, międzynarodowych pojedynków sportowych. Znaczna część turystów odwiedza dane miejsce tylko i wyłącznie ze względu na uczestnictwo w wydarzeniu, które właśnie tam się odbywa. W świetle przeprowadzonych badań wśród respondentów biorących udział w Memoriale Huberta Jerzego Wagnera oraz Mistrzostwach Europy Siatkarzy 2017 wyciągnięto pewne wnioski na temat przebadanej próby. Eventy sportowe różnej rangi są jednym z czynników wpływających na rozwój turystyki na obszarach goszczących. Imprezy typu mistrzowskiego przyciągają większą liczbę osób spoza obszaru, w którym się odbywają. Osoby te łączą kibicowanie ze zwiedzaniem miejsca, w którym przebywają. Planowały spędzić w Krakowie więcej dni (3-4 dni i dłużej) niż uczestnicy Memoriału Huberta Jerzego Wagnera (1 dzień bez noclegu bądź 2 dni) oraz częściej korzystały z krakowskiej bazy noclegowej. Największą kategorię wydatków stanowiły koszty związane z wyżywieniem. Badani uczestniczący w wydarzeniach siatkarskich, poza udziałem w meczach, planowali także skorzystać z bogatej oferty kulturalnej Krakowa. Jako najważniejsze atrakcje turystyczne wskazywano Wawel, Sukiennice oraz Fabrykę Oskara Schindlera. Stwierdzono, że kibice podejmują dodatkową aktywność przy okazji udziału w wydarzeniach sportowych, co wpływa na rozwój turystyki na obszarze goszczącym. Jednak ze względu na niewielką grupę badawczą niemożliwe jest wyciągnięcie jednoznacznych wniosków. Rekomenduje się ponowne przeprowadzenie badań na większej grupie respondentów.

\section{Literatura}

Bączek J.B. (2011). Psychologia eventów. Wydawnictwo Stageman Polska.

Freyer W. (1998). Event-Management im Tourismus. Kulturveranstaltungen \& Festivals als touristische Leistungsangebote. W: W. Freyer, D. Meyer, K. Scherhag (red.), Events - Wachstumsmarkt im Tourismus? Tagungsband zum 3. Dresdner Tourismussymposium, Dresden, s. 17-50.

Getz D. (2005). Event management \& Event tourism. Cognizant Communication Corporation.

Piotrowski P. (2012). Determinanty skuteczności wydarzeń marketingowych w tworzeniu turystycznego wizerunku miasta. W: T. Żabińska (red.), Turystyka na obszarach miejskich - uwarunkowania rozwoju. Narzędzia promocji. Studia Ekonomiczne, Zeszyty Naukowe Wydziałowe Uniwersytetu Ekonomicznego w Katowicach.

Poczta J., Malchrowicz-Mośko E. (2016). Wpływ eventów sportowych na rozwój turystyki w mieście na przykładzie poznańskich imprez sportowych. Journal of Education, Health and Sport, 6(4): 151-166. 
Proszowska-Sala A., Florek M. (2004). Promocja miasta. Nowa perspektywa. Stroer.

Richards B. (2004). Marketing atrakcji turystycznych - jak zwiększyć frekwencję i dochody. Polska Organizacja Turystyczna, Warszawa.

Stępowski R. (2018). Wpływ i działanie promocyjne polskich miast i regionów. Edycja 2018 (http://marketingmiejsca.com.pl/media/uploaded/raport4-0y34mwy5/Raport_2018.pdf; dostęp: 10.01.2021).

Willems H. (2000). Events: Kultur - Identität - Marketing. W: W. Gebhardt, R. Hitzler, F. Liebl Events (red.), Soziologie des Außergewöhnlichen. Opladen.

\section{Sporting events as a factor in the development of tourism in host areas (on the example of volleyball events organized in Krakow)}

Krakow can be a place for great sports events thanks to its perfect communication location and sports infrastructure like TAURON Arena Krakow. Apart from theoretical and terminological issues, the article contains an analysis of the impact of the Hubert Jerzy Wagner Memorial and the 2017 European Volleyball Championships on the economy of Krakow in the light of own empirical research. The research aimed to show the extent to which fans undertake additional tourist activity in the city while participating in these events. Championship volleyball events generate more tourist traffic and attract more people from outside the area where they are held. These people combine cheering with visiting the place where they are staying, they stay longer in Krakow and want to take advantage of a wide range of cultural offers. 